\title{
Impact of Financial Knowledge, Financial Attitude and Financial Behaviour on Financial Literacy: Structural Equitation Modeling Approach
}

\author{
Dhananjay Banthia, Sanjeeb Kumar Dey* \\ Department of Commerce, Ravenshaw University, Odisha-753003, India \\ Received September 21, 2021; Revised October 17, 2021; Accepted December 1, 2021
}

\section{Cite This Paper in the following Citation Styles}

(a): [1] Dhananjay Banthia, Sanjeeb Kumar Dey, "Impact of Financial Knowledge, Financial Attitude and Financial Behaviour on Financial Literacy: Structural Equitation Modeling Approach," Universal Journal of Accounting and Finance, Vol. 10, No. 1, pp. 327 - 337, 2022. DOI: 10.13189/ujaf.2022.100133.

(b): Dhananjay Banthia, Sanjeeb Kumar Dey (2022). Impact of Financial Knowledge, Financial Attitude and Financial Behaviour on Financial Literacy: Structural Equitation Modeling Approach. Universal Journal of Accounting and Finance, 10(1), 327 - 337. DOI: 10.13189/ujaf.2022.100133.

Copyright $\bigcirc 2022$ by authors, all rights reserved. Authors agree that this article remains permanently open access under the terms of the Creative Commons Attribution License 4.0 International License

\begin{abstract}
Financial literacy has gained importance in recent years and has become a major issue all around the world. The financial market offers a wide range of products in a complicated manner and product accessibility has also risen. As a result, it is critical for individuals to have the appropriate financial knowledge and awareness in order to make the utmost use of their financial resources. Due to the massive population, poor literacy levels, poverty, disparities in regional languages, diverse cultures, and wide socio-economic disparities, the path to a financially literate in India is also difficult. Further, the behaviour and attitudes of an individual are influenced by the enormous range of culture, beliefs, religion, and customs found in different states. Under such circumstances, this research is conducted to determine the way financial literacy is linked to financial knowledge, financial attitude and financial behaviour in Odisha, India. It is found that there is a negative effect of "Financial Behaviour" on "Financial literacy level". "Financial knowledge" is found to be positively related to "Financial behaviour" and "Financial attitude". But, "Financial attitude \& Financial behaviour" are negatively related.
\end{abstract}

Keywords Financial Literacy, Financial Knowledge, Financial Attitude and Financial Behaviour, SEM

\section{Introduction}

Since globalization has kept pace in creating rapid development across countries, financial literacy has become increasingly important for achieving greater economic success. Not only in India, but also in many other rising economies throughout the world, there has been a remarkable increase in financial literacy awareness campaigns in last two decades. Financial literacy is defined as the ability to ensure that one has a complete understanding of financial markets and goods. It informs consumers about the risks and rewards of various investment opportunities and helps them make well-informed decisions. Over the years, financial literacy has grown increasingly crucial, with all players, from regulators to policymakers to financial institutions. The capacity to make wise financial decisions is becoming increasingly vital in today's fast changing world, necessitating financial literacy. Financial literacy skill is determined by an individual's financial understanding [22], [24]. It is described as the capability to recognize and comprehend financial market items to make informed decisions. As a result, financial literacy is primarily concerned with personal money in order to empower individuals to take effective action to prevent financial suffering. People who are financially literate are quite confident to take any decision while managing their financial issues, and their financial outcomes are better. It 
is therefore essential for people to have an adequate level of financial literacy that would be helpful to improve their living standard [8].

The confidence with which a person applies the information and understanding to make good financial decisions is commonly known as financial literacy. To provide people the tools, they need to make better financial decisions, one must first examine what they know and then evaluate what they need to know [14]. As the massive group of people in India is not the part of the formal financial system, it necessitates the increase of financial literacy. In this context, the importance of financial literacy is gradually increasing, and it may be a determining factor in such groups' ability to access money. Conceptually financial literate people are more knowledgeable and are more capable of doing all types financial transactions. It is viewed as a foundational concept that can assist people in avoiding financial difficulties [11]. Financial literacy focuses on the dimensions-financial knowledge, behaviour, and attitude [25]. It is positively related to financial knowledge, behaviour, and attitude [1]. The knowledge of finance adds to the development of financial management behaviour since it is made up of financial education and experience that can help to improve financial knowledge and thus make financial decision making more effective. Individuals with low financial knowledge are unaware of the various aspects of investment pattern. Financial behaviour blends behavioural and cognitive psychology with traditional economics and finance to understand why people engage in irrational behaviour while managing their financial decisions [19]. The paper undertakes the study of the relation of financial literacy with financial knowledge, financial attitude and financial behaviour of the people of Odisha.

\section{Review of Literature}

\subsection{Financial Literacy}

Financial literacy is a favorable attitude toward making decisions based on financial information that might influence an individual the way he/she derives monetary pleasure. It is a mindset that can improve the financial situation of an individual by influencing his/her financial management techniques [5]. Financial literacy is described as an individual's capacity in applying the knowledge to build suitable financial decisions [23]. Financial literacy is the knowledge that enables people to comprehend what, how, why, where, and when to spend money. Financial literacy teaches people how to apply what they've learned in the classroom to attain future success and happiness. As a result, there is an improvement in life satisfaction as an effect of high financial levels [20]

\subsection{Financial Knowledge}

Understanding of money and financial concepts is one of the criteria to judge financial knowledge of a person. Increased financial knowledge might alter risk perceptions when it comes to investment options. Individuals with high financial knowledge, on the other hand, have a higher value of life satisfaction. It is believed that the more financial knowledge, the better will be the financial management behaviour of a person [2]. Financial knowledge refers to someone's comprehension of a subject of finance that is very significant to them, like managing budget and planning for saving [4]. Financial attitude is a psychological inclination of a person when analyzing the financial management practices [18].

\subsection{Financial Attitude}

A person's financial attitude is crucial in shaping their financial management behaviour. As a result, one can observe that the more affirmative a person's financial attitude is, the better his or her money management behaviour [16]. Financial attitude is the reaction of an individual with regard to own financial troubles as a result of a response to a financial statement or viewpoint. Thus, financial attitudes can be characterized as a mental state of an individual while dealing money matters [15]. The term financial attitude refers to a physical embodiment of financial principles for making and assessing financial decisions [21].

\subsection{Financial Behaviour}

Financial position of respondents is another factor that influences personal financial behavior. One of the qualities used to determine a person's financial literacy level is his comprehension of monetary perceptions. Financial behaviour is the set of performed actions involving activities in the areas of financial activities [18]. The way that an individual saves, invests and manages his/her expenditure and credit are the common indicators of financial behaviour [7]. The ability of a person to manage the cash in hand is the most important sign of financial health since it considers a person's capacity to meet all of their financial responsibilities. Timely payment of bills, keeping the track of all payments and the planning of all future financial transactions are considered as the indicators of good financial management behaviour [11]. Investment is a commitment to postpone the purchase of one or more assets in the near future and it symbolizes financial behaviour [10].

\section{Objectives of the Study}

The objective of the study is to analyze the relationship of financial literacy with financial knowledge, financial attitude and financial behaviour.

The following hypotheses are developed to test the objective of the research. 
- H1: Financial knowledge has positive impact on financial literacy

- H2: Financial attitude has positive impact on financial literacy

- H3: Financial behavior has positive impact on financial literacy

- H4: Financial knowledge, financial attitude and financial behavior are positively related

\section{Research Methodology}

\subsection{Model Development}

Financial literacy is often regarded as a necessary life skill in today's ever-increasingly complex markets. It is a big challenge for all countries throughout the world. People usually face hurdles in today's continuously changing and financially sophisticated environment. In comparison to previous generations, today's financial situation is far more complicated. To take advantage of financial developments, they need to improve their financial skills. Grable, [9] found that those with a lower level of financial risk tolerance have trouble making financial decisions and are discontented with their money management skills. Financial knowledge has a powerful impact on financial attitudes and behavior [22]. The current study attempts to examine the relationship of financial knowledge (FK), financial attitude (FA), and financial behavior (FB) with the financial literacy (FL) level of people of Odisha, India.
The figure 1 reflects the proposed model for examining the relationship between the variables.

\subsection{Research Design}

This is an analytical research study in which financial literacy is measured using a multidimensional construct. The participants are selected with an emphasis on including both male and female of all age groups with different educational backgrounds. Both primary and secondary data have been used for the study. Various information about financial literacy has been gathered from the secondary sources, and the primary data based on 756 sample participants have been collected through a well-designed questionnaire during two-month period of 2020.

\subsection{Population of the Study}

Odisha, a state on India's eastern coast, is divided into 30 districts. To streamline their governance, these 30 districts have been divided into three revenue divisions. Out of 559 districts in the country, Khordha is the most developed and richest district in the state, with a rank of 104, while Cuttack is the second most developed district with a rank of 169. The research is thus decided to be conducted in these two districts with a total population of $8,81,988$ in Khordha and 6, 58,986 population in Cuttack. The total population of the study is limited to $15,40,974$.

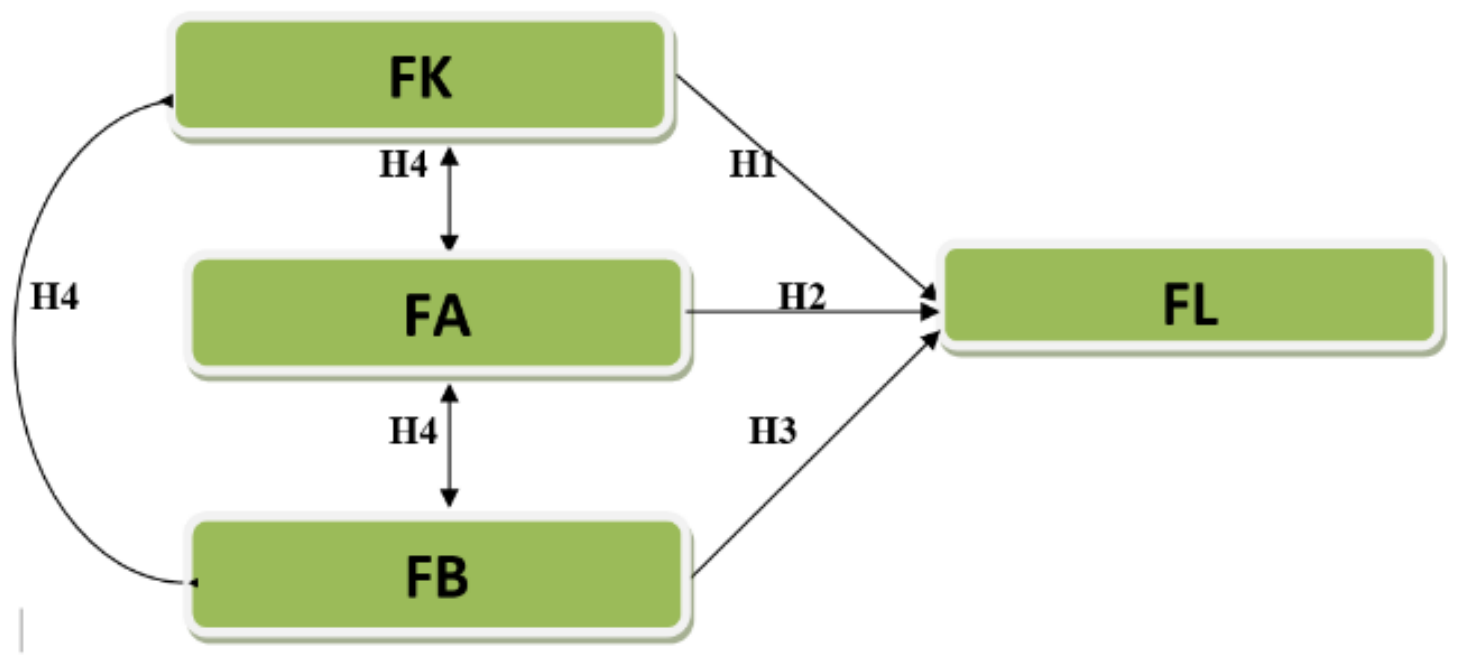

Figure 1. Proposed Model for the study 


\subsection{Sample Size Justification}

The sample size decision is tested as follows.

$$
\mathrm{n}=\frac{\frac{\mathrm{z}^{2} \mathrm{p}(1-\mathrm{p})}{\mathrm{e}^{2}}}{1+\frac{\mathrm{z}^{2} \mathrm{p}(1-\mathrm{p})}{\mathrm{Ne}^{2}}},=1067
$$

The total population of each district constitutes the sub-population size $\left(N_{i}\right)$ of each district.

$\mathrm{N}=$ Population size (total population in two districts) = $15,40,974$

$P=$ Proportion of respondents $=0.5$

$\mathrm{e}=$ Margin error $=4 \%$

$\mathrm{Z}=$ Critical value for large sample at $95 \%$ confidence level $=1.96$

The total number of people to be selected from each district is decided by using stratified sampling with following rule.

$\mathrm{n}=$ Total Sample size $=1067$

$\mathrm{N}=$ Population size $=10105798$

$\mathrm{n}_{\mathrm{i}}=\frac{\mathrm{n}}{\mathrm{N}} \mathrm{N}_{\mathrm{i}}$

Table 1. Sample size

\begin{tabular}{|c|c|c|}
\hline District & Population & Sample size \\
\hline Khordha & 881988 & 611 \\
\hline Cuttack & 658986 & 456 \\
\hline Total & 1540974 & 1067 \\
\hline
\end{tabular}

It thus decided to include a total of 1067 people in the study, 611 people from Cuttack and 465 from Khordha.

\subsection{Questionnaire Development}

A well-designed questionnaire pertaining to various dimensions of the constructs of the study was prepared based on the literatures reviewed (table-2). Seven items were selected as the indicators of financial knowledge (FK) covering the aspects of saving, calculating interest rate, understanding the value of money, risk-reward ratio, familiarity with electronic transactions, awareness of return and knowledge of inflation. People who act responsibly when it comes to money and finances are more likely to enjoy a secure financial future than those who act carelessly. Apart from information, people's attitudes play a critical role in shaping their financial future. As such seven items were used as the indicators of financial attitude (FA) that can reflect people's attitudes about short-term/long-term future planning, spending/saving priorities, knowledge of financial products, ability to manage financial activities, understanding the role of agents, financial awareness and the information about different investment avenues. In the similar manner, seven items were selected further to assesses financial behaviour (FB) of people, such as paying bills on time, keeping track of financial status, minimizing dependency on loans, developing plans for future financial requirements, eliminating waste, thinking before shopping, and the habits of keeping the records of all financial matters. Financial literacy (FL) level of the participants was examined on three levels- low level, moderate level and high level. The selection of items under each construct was based on their acceptable range of reliability and validity. The questionnaire was prepared on each item under the constructs on 5-points likert scale. Where, 5 indicates strongly disagree and 1-indicates strongly agree attitude to that particular item/statement. A total of 1100 questionnaire were prepared and distributed among the participants, 900 participants returned the questionnaire but, 756 questionnaires were found in complete form. Thus it was possible to collect the data from 756 participants only (389 from Cuttack and 367 from Khordha). Thus, the sample size is restricted to 756 only. 
Table 2. Questions and parameters of model:

\begin{tabular}{|c|c|c|c|c|c|c|}
\hline & FINANCIAL KNOWLEDGE & & & & & \\
\hline 1 & I am quite confident with basic numerical calculations without any mistakes & 1 & 2 & 3 & 4 & 5 \\
\hline 2 & I am quite sure about the calculation of simple interest & 1 & 2 & 3 & 4 & 5 \\
\hline 3 & I know the calculation of amount in case of compound interest & 1 & 2 & 3 & 4 & 5 \\
\hline 4 & I have the knowledge about the high level of risk with high return. & 1 & 2 & 3 & 4 & 5 \\
\hline 5 & I know that high inflation leads to increase the cost of living & 1 & 2 & 3 & 4 & 5 \\
\hline 6 & I know that the value of money changes with time. & 1 & 2 & 3 & 4 & 5 \\
\hline \multirow[t]{2}{*}{7} & I am quite confident of using various electronic transactions. & 1 & 2 & 3 & 4 & 5 \\
\hline & FINANCIAL ATTITUDE & & & & & \\
\hline 1 & I always stay informed about financial planning & 1 & 2 & 3 & 4 & 5 \\
\hline 2 & I have the knowledge of personal financial awareness. & 1 & 2 & 3 & 4 & 5 \\
\hline 3 & I have the knowledge of different financial products. & 1 & 2 & 3 & 4 & 5 \\
\hline 4 & I stay informed about different investment avenues. & 1 & 2 & 3 & 4 & 5 \\
\hline 5 & I always stay informed about stock market activities & 1 & 2 & 3 & 4 & 5 \\
\hline 6 & I am confident about managing my financial matters & 1 & 2 & 3 & 4 & 5 \\
\hline \multirow[t]{2}{*}{7} & I clearly understand the role of agents in investing & 1 & 2 & 3 & 4 & 5 \\
\hline & FINANCIAL BEHAVIOUR & & & & & \\
\hline 1 & My financial condition can meet all my financial needs only & 1 & 2 & 3 & 4 & 5 \\
\hline 2 & I spend money than to save it for the long term & 1 & 2 & 3 & 4 & 5 \\
\hline 3 & I believe in paying my bills on time & 1 & 2 & 3 & 4 & 5 \\
\hline 4 & My financial condition restricts me to do some important things in my life. & 1 & 2 & 3 & 4 & 5 \\
\hline 5 & I keep a close watch on my financial affairs & 1 & 2 & 3 & 4 & 5 \\
\hline 6 & I have the habits of keeping the records of all of my financial activities & 1 & 2 & 3 & 4 & 5 \\
\hline 7 & $\begin{array}{l}\text { I have the tendency to analyze my affordability before buying } \\
\text { LEVEL OF FINANCIAL LITERACY } \\
\text { 1. Low level } \\
\text { 2. Moderate level } \\
\text { 3. High level }\end{array}$ & 1 & 2 & 3 & 4 & 5 \\
\hline
\end{tabular}

\subsection{Variables and Methods}

Structural Equation Modeling has been employed to analyze the data. In recent years, structural equation modeling has become more widely employed in scientific studies in the field of social sciences. The fact that a single model can measure both direct and indirect correlations among causative variables is the most fundamental reason for the spread of this statistical technique. The structural equation model, in general, depicts the predicted cause and effect relationship between several constructs with statistical dependencies. The primary data so collected were analyzed by using SPSS-AMOS-23.

\section{Results and Discussion}

\subsection{Profile of Respondents}

A complete description of sample respondents is tabulated in table no-3. 
Table 3. Respondents' profile

\begin{tabular}{|c|c|c|}
\hline Gender & Number & Percentage \\
\hline Male & 484 & Percentage \\
\hline Female & 272 & 15 \\
\hline Age & Number & 27 \\
\hline Below 30 & 113 & 35 \\
\hline $30-40$ & 204 & 23 \\
\hline $40-50$ & 265 & Percentage \\
\hline 50 and more & 174 & 41 \\
\hline Education & Number & 42 \\
\hline Under graduate & 83 & Percentage \\
\hline Graduate & 355 & 42 \\
\hline Post graduate/ Others & 318 & 31 \\
\hline Occupation & Number & 27 \\
\hline Govt./private employee & 318 & 51 \\
\hline Business & 23418 & Percentage \\
\hline Professional & 204 & 49 \\
\hline District & Number & \\
\hline Khordha & 367 & \\
\hline Cuttack & & \\
\hline
\end{tabular}

Source: Compiled from collected data

Majority of the respondents are male graduates of the age group (40-50) employed in government or private organizations.

\subsection{Reliability}

Table 4. Reliability

\begin{tabular}{|c|c|c|}
\hline Constructs & Cronbach's Alpha & N \\
\hline FK & 0.874 & 7 \\
\hline FA & 0.926 & 7 \\
\hline FB & 0.948 & 7 \\
\hline
\end{tabular}

The values of Alpha for all the constructs are more than 0.70 (table-4), indicating a strong level of internal consistency reliability for the scale used as measuring instrument.

\subsection{Convergent Validity}

Convergent validity is established through "Composite reliability (CR)" and "Average Variance explained (AVE)" and it measures relationship between two constructs. The collected data set meets the validity test if $\mathrm{CR}>0.7, \mathrm{CR}>$ $\mathrm{AVE}$ and AVE $>0.5$ [12]. The calculated values of $\mathrm{CR}$, AVE (table-5) for all the constructs meet the minimum requirement for the data to be reliable. 
Table 5. Validity

\begin{tabular}{|c|c|c|c|c|c|}
\hline & & & & AVE & CR \\
\hline L1 & $<---$ & FK & 0.636 & \multirow{7}{*}{0.5014} & \\
\hline L2 & $<---$ & FK & 0.627 & & \\
\hline L3 & $<---$ & FK & 0.686 & & \\
\hline L4 & $<---$ & FK & 0.821 & & \\
\hline L5 & $<---$ & FK & 0.788 & & \\
\hline L6 & $<---$ & FK & 0.766 & & \\
\hline L7 & $<---$ & FK & 0.555 & & 0.870 \\
\hline L8 & $<---$ & FA & 0.902 & \multirow{7}{*}{0.6200} & \\
\hline L9 & $<---$ & FA & 0.805 & & \\
\hline L10 & $<---$ & FA & 0.865 & & \\
\hline L11 & $<--$ & FA & 0.769 & & \\
\hline L12 & $<---$ & FA & 0.639 & & \\
\hline L13 & $<---$ & FA & 0.85 & & \\
\hline L14 & $<---$ & FA & 0.639 & & 0.9183 \\
\hline L15 & $<---$ & FB & 0.844 & \multirow{7}{*}{0.7258} & \\
\hline L16 & $<---$ & FB & 0.854 & & \\
\hline L17 & $<---$ & FB & 0.816 & & \\
\hline L18 & $<--$ & FB & 0.879 & & \\
\hline L19 & $<---$ & FB & 0.896 & & \\
\hline L20 & $<---$ & FB & 0.782 & & \\
\hline L21 & $<---$ & FB & 0.887 & & 0.9487 \\
\hline
\end{tabular}

\subsection{Discriminant Validity}

The extent different constructs are different from each other is determined by Discriminant validity. The sample data confirm this validity (Table 6) as MSV $<$ AVE, ASV $<$ AVE and $\sqrt{ }$ AVE $>$ Correlation [12].

Table 6. Factor Correlation Matrix

\begin{tabular}{|c|c|c|c|c|c|c|}
\hline & MSV & AVE & ASV & FK & FA & FB \\
\hline FK & 0.043681 & 0.5014 & 0.02184 & 0.708 & 0.004 & 0.209 \\
\hline FA & 0.000016 & 0.62 & 0.000092 & 0.004 & 0.774 & -0.013 \\
\hline FB & 0.04368 & 0.7258 & 0.0201925 & 0.209 & -0.013 & 0.851 \\
\hline
\end{tabular}

\subsection{Model Fit Summary}

Different measures of goodness of fit are as follows.

Table 7. Model Fit

\begin{tabular}{|c|c|c|}
\hline Variable & Value(Model-I) & Suggested value \\
\hline "Chi-square value" & 464.802 , d.f $=200$ & \\
\hline "P value" & 0.000 & \\
\hline “CMIN/DF" & 2.324 & $"<3 "$ \\
\hline “GFI" & 0.945 & $">0.90 "$ \\
\hline "AGFI" & 0.930 & $">0.90 "$ \\
\hline "CFI" & 0.978 & $">0.90 "$ \\
\hline "RMR" & 0.064 & $"<0.08 "$ \\
\hline "RMSEA" & 0.042 & "<0.08" \\
\hline "P-CLOSE" & 0.997 & $">0.05 "$ \\
\hline
\end{tabular}


All the model fit (table no-7) indices are within the suggestive range [3], [6], [13]. The particular model is obtained by co-variating the error terms e1 with e21; e8 with e 10 and e 7 with e9 and it is evident from the following path diagram (fig-2).

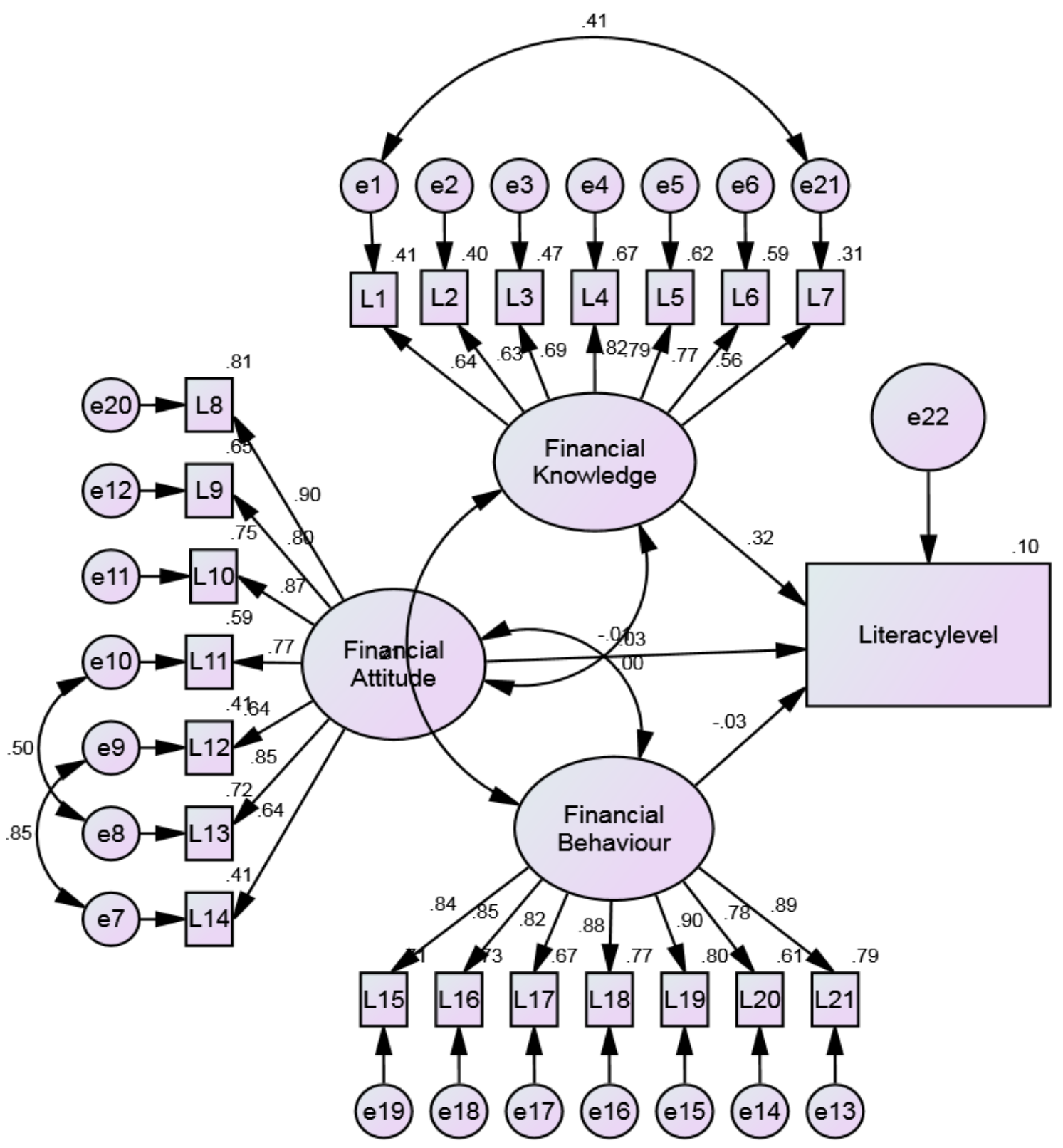

Figure 2. Final model for measuring Financial Literacy 
Table 8. Regression Weights and critical ratios

\begin{tabular}{|c|c|c|c|c|c|c|}
\hline & & & Estimate & S.E. & C.R. & $\mathbf{P}$ \\
\hline L1 & $<---$ & FK & 1 & & & \\
\hline L2 & $<---$ & FK & 0.998 & 0.068 & 14.683 & $*$ \\
\hline L3 & $<---$ & FK & 1.071 & 0.068 & 15.782 & $*$ \\
\hline L4 & $<---$ & FK & 1.257 & 0.07 & 17.987 & $*$ \\
\hline L5 & $<---$ & FK & 1.204 & 0.069 & 17.503 & $*$ \\
\hline L6 & $<---$ & FK & 1.189 & 0.069 & 17.154 & $*$ \\
\hline L7 & $<---$ & FK & 0.84 & 0.051 & 16.512 & $*$ \\
\hline L8 & $<---$ & FA & 1.383 & 0.069 & 20.16 & $*$ \\
\hline L9 & $<---$ & FA & 1.215 & 0.065 & 18.59 & $*$ \\
\hline L10 & $<---$ & FA & 1.339 & 0.068 & 19.61 & $*$ \\
\hline L11 & $<---$ & FA & 1.129 & 0.063 & 17.905 & $*$ \\
\hline L12 & $<---$ & FA & 1.006 & 0.025 & 39.642 & $*$ \\
\hline L13 & $<---$ & FA & 1.287 & 0.067 & 19.345 & $*$ \\
\hline L14 & $<---$ & FA & 1 & & & \\
\hline L15 & $<---$ & FB & 0.956 & 0.03 & 32.301 & $*$ \\
\hline L16 & $<--$ & FB & 0.988 & 0.03 & 33.1 & $*$ \\
\hline L17 & $<---$ & FB & 0.95 & 0.031 & 30.227 & $*$ \\
\hline L18 & $<---$ & FB & 1.024 & 0.029 & 35.249 & $*$ \\
\hline L19 & $<---$ & FB & 1.032 & 0.028 & 36.773 & $*$ \\
\hline L20 & $<---$ & FB & 0.941 & 0.034 & 28.003 & $*$ \\
\hline $\mathrm{L} 21$ & $<--$ & FB & 1 & & & \\
\hline FL & $<---$ & FK & 0.505 & 0.069 & 7.319 & $*$ \\
\hline FL & $<---$ & FA & 0.057 & 0.053 & 1.087 & 0.277 \\
\hline FL & $<---$ & FB & -0.027 & 0.04 & -0.68 & 0.496 \\
\hline
\end{tabular}

Table 9. Covariances among the variables

\begin{tabular}{|c|c|c|c|c|c|c|}
\hline & & & Estimate & S.E. & C.R. & P \\
\hline FK & $<-->$ & FB & .219 & .044 & 5.009 & $*$ \\
\hline FA & $<->$ & FB & -.015 & .043 & -.337 & .736 \\
\hline FK & $<->$ & FA & .003 & .032 & .088 & .930 \\
\hline
\end{tabular}

In table-8, the value of critical ratios (C.R) getting more than 1.96 is an indication of the significance of the path with $95 \%$ confidence level. Similarly, the P-value with (*) indicates that the regression weights are significant. As such, the effect of all the observed variables has significant loading on their constructs. The effect of "Financial Knowledge" on "Financial literacy" is positive and significant. But, the effect of "Financial Attitude" on "literacy level" is positive and insignificant. Similarly, the effect of "Financial Behaviour" on "literacy level" is negative and insignificant. So, $\mathrm{H} 1$ and $\mathrm{H} 2$ are accepted and $\mathrm{H} 3$ is rejected.

The covariance (table-9) between "financial attitude \& financial behaviour" is negative and not significant as C.R is less than 1.96. The covariance between "financial knowledge \& financial behaviour" is positive and significant as C.R is more than 1.96. Similarly, the covariance between "financial knowledge \& financial attitude" is positive and not significant. The negative covariance value indicates negative correlation between the constructs- "financial attitude \& financial behaviour". So, H4 is accepted for "financial knowledge \& financial behaviour" and "financial knowledge \& financial attitude", but it is rejected for the relation between "financial attitude $\&$ financial behaviour".

\section{Limitations of the Study}

The study is sensitive in nature as it is based on the 
determinants of financial literacy level of people of Odisha. Thus the information supplied by the participants may not reflect the true picture and consequently the results of the study may not be generalized. Similarly, the information collected during a short time period is not sufficient to cover all aspects of the variables under study, creating limitations of the research.

\section{Findings and Conclusions}

Financial literacy refers to a collection of skills, knowledge, attitudes, and behaviour that enable people to effectively use financial services. Financial literacy increases an individual's quality of life. It aids in the provision of basic budgeting tools, as well as the development of saving discipline, ensuring that people can benefit and enjoy a pleasant life. Individuals with financial knowledge can aid the economy by encouraging healthy competition and encouraging service providers to raise their level of competitiveness. It is now vital to increase financial literacy knowledge because it can reduce the possibility of being misled while making investment decisions. The research identified positive effect of "Financial Knowledge" and "Financial Attitude" on "Financial literacy level", supported by (Atkinson and Messy [1]). But, there is a negative effect of "Financial Behaviour" on "Financial literacy level". And so, "Financial Knowledge" and "Financial Attitude" are the significant indicators of "Financial Literacy level" of people of Odisha. Similarly, "Financial knowledge" is found to be positively related to "Financial behaviour" and "Financial attitude", supported by Arifin [2]. But, "Financial attitude \& Financial behaviour" are negatively related. It is therefore interpreted that paying bills on time, keeping track of all financial transactions, developing plans for future financial requirements etc. cannot reflect the attitudes about short-term/long-term future planning, spending/saving priorities of people of Odisha. In the same way, the spending and saving patterns are not the indicators of good financial literacy level of people of Odisha. Financial literacy could be considered as the first step to poverty reduction and development in poor countries. It is indeed more significant in Odisha because a large portion of the population, particularly in rural regions, lacks access to conventional financial services.

Financial literacy is a problem that affects nearly every country on the planet. A suitable level of financial literacy is essential for a person's financial prosperity. Poor money management skills of people are thus making them more vulnerable to a financial catastrophe. It is now vital to raise financial literacy knowledge because it can reduce the possibilities of being misled while making investment decisions. The major finding of this research aids in the understanding of financial behaviour of Indian in general and the people of Odisha in particular. The current work provides information to help people of Odisha to increase the financial literacy level.

\section{REFERENCES}

[1] Atkinson, A., Messy, F. A., "Measuring financial literacy: Results of the OECD/International Network on Financial Education (INFE) pilot study," OECD Working Papers on Finance, Insurance and Private Pensions, No. 15, OECD Publishing, Paris. 2012. DOI 10.1787/5k9csfs90fr4-en.

[2] Arifin, A. Z., Kevin, Siswanto, H. P., "The Influence of Financial Knowledge, Financial Confidence and Income on Financial Behaviour Among the Workforce in Jakarta," MIX: JurnalIlmiahManajemen, vol. 7, no. 1, pp. 37-47, 2017.

[3] Bentler, P. M., \&Bonett, D. G., "Significance tests and goodness of fit in the analysis of covariance structures," Psychological Bulletin, vol. 88, no. 3, pp. 588-606, 1980.

[4] Chowa, G. A. N., Despard, M. R., Osei-Akoto, I., "Youth saving patterns and performance in Ghana." (Youth Save Research Brief No. 12-36), St. Louis, MO: Washington University, Center for Social Development.2012. DOI: https://doi.org/10.7936/K7668CQ5

[5] Chen, H., Volpe, R. P., "An analysis of personal financial literacy among college students," Financial Services Review, vol. 7, no. 2, pp. 107-128, 1998.

[6] Daire, H., Joseph, C., Michael, RM., "Structural Equation Modeling: Guidelines for Determining Model Fit," Electron Journal of Business Research Methods, vol. 6, no. 1, pp.53-60, 2008.

[7] Dew, J., Xiao, J. J., "The Financial Management Behavior Scale: Development and Validation," Journal of Financial Counseling and Planning, vol. 22, no. 1, pp.43-59, 2011.

[8] De BassaScheresberg, C., "Financial literacy and financial behavior among young adults: Evidence and implications," Numeracy Advancing Education in Quantitative Literacy, vol. 6, no. 2, pp. 1-21, 2013. DOI: 10.5038/1936-4660.6.2.5

[9] Grable, J. E., Park, J.-Y., \& Joo, S.-H. (2009). Explaining financial management behavior for Koreans living in the United States. Journal of Consumer Affairs, 43(1), 80107. https://doi.org/10.1111/j.1745-6606.2008.01128.x

[10] Jones, J. E., "College students' knowledge and use of credit," Journal of Financial Counseling and Planning, vol. 16, no. 2, pp. 9-16, 2005.

[11] Hilgert, M. A., Hogarth, J. M., Baverly, S., "Household Financial Management: The Connection between Knowledge and Behavior," Federal Reserve Bulletin, vol. 89, no. 7, pp. 309-322. 2003.

[12] Hair, J.F., Tatham, R.L., Anderson, R.E., Black, W, "Structural equation modeling overview," in Multivariate Data Analysis, $7^{\text {th }}$ ed, PPH, 2010, pp. 604-761.

[13] Hu, L., Bentler, P. M., "Cutoff criteria for fit indexes in covariance structure analysis: Conventional criteria versus new alternatives," Structural Equation Modeling: A Multidisciplinary Journal, vol. 6, no. 1, pp. 1-55, 1999. DOI: $10.1080 / 10705519909540118$ 
[14] Lusardi, A., Mitchell, O. S., Curto, V, "Financial literacy among the young," Journal of Consumer Affairs, vol. 44, no. 2, pp. 358-380, 2010.

[15] Marsh, B. A., "Examining the Personal Financial Attitudes, Behavior and Knowledge Levels of First Year and Senior Students at Baptist Universites in the State of Texas," Bowling Green State University, http://rave.ohiolink.edu/e $\mathrm{tdc} / \mathrm{view}$ ?acc num=bgsu1151189375 (accessed on $1 \mathrm{Jul}$., 2021)

[16] Mien, T., "Factors Affecting Personal Financial Management Behavior: Evidence from Vietnam." The Second Asia-Pacific Conference on Global Business, Economics, Finance and Social Sciences, Vietnam: University of Economics Ho Chi Minh City.July, 2015, pp. $1-16$.

[17] Nurkhodzha Akbulaev, Matanat Mammadova (2021). Demographic Analysis of Financial Literacy Level in Azerbaijan. Universal Journal of Accounting and Finance, 9(3), 316 - 328. DOI: 10.13189/ujaf.2021.090305.

[18] Parrotta, J. L., Johnson, P. J., Jodi L. Parrotta and Phyllis J. Johnson, "The impact of financial attitudes and knowledge on financial management and satisfaction of recently married individuals," Association for Financial Counselling and Planning, vol. 9, no.2, pp. 59-75, 1998.

[19] Phung, A., "Behavioral Finance: Introduction," New York: Investopedia, https://www.investopedia.com/contributors/30/ (accessed on 10 Jul., 2021)

[20] Pankow, D., "Financial, Values, Attitudes and Goals," NorthDakota State University Fargo, https://www.ag.ndsu. edu (accessed Aug. 8, 2021)

[21] Rajna, A., Ezat, W.S., Junid, S.A., Moshiri, H., "Financial Management Attitude and Practice among the Medical Practitioners in Public and Private Medical Service in Malaysia," International Journal of Business and Management, vol. 6. no. 8, pp. 105-113, 2011. DOI:10.5539/ijbm.v6n8p105

[22] Robb, C. A. and Woodyard, A. S., "Financial Knowledge and Best Practice Behavior," Journal of Financial Counseling and Planning, vol.22, no. 1, pp. 60-87, 2011.

[23] Sanderson, A., "Importance of financial literacy," Bankers Association of Zimbabwe (BAZ) Newsletter, http://www.baz.org.zw (accessed Aug. 22, 2021)

[24] Woodyard, A. S. and Robb, C. A., "Consideration of Financial Satisfaction: What Consumers Know, Feel and Do from a Financial Perspective," Journal of Financial Therapy, vol. 7, no. 2, pp. 41-61, 2016. DOI: 10.4148/1944-9771.1102

[25] Velumani, M., Mathavathani, V., "A study on financial literacy among rural women in Tamil Nādu," Indian Journal of Applied Research, vol. 4, no. 12, pp. 556-557,2014 